\title{
ДО ХАРАКТЕРИСТИКИ ФОРМ ЗАХИСТУ ТРУДОВИХ ПРАВ МІГРАНТІВ
}

\begin{abstract}
Анотація. У статті на основі аналізу наукових поглядів учених та норм чинного законодавства України з'ясовано коло та надано характеристику ключовим формам захисту трудових прав мігрантів. Відзначено, що форми захисту трудових прав мігрантів доцільно класифікувати на юрисдикційні та неюрисдикційні. Обгрунтовано, що специфіка реалізації визначених у статті форм зумовлена особливістю правового статусу мігранта, законністю його перебування на території країни. Наголошено, що серед спеціальних форм захисту трудових прав та законних інтересів можна виділити адміністративний захист, який включає у себе захист державними органами, які здійснюють контроль дотримання трудового законодавства. 3'ясовано, що значення форм захисту трудових прав мігрантів полягає у тому, що їх правове регулювання визначає: 1) можливе коло суб'єктів, що приймають участь у відносинах із захисту трудових прав мігрантів за такої форми; 2) певну модель поведінки учасників правовідносин із захисту трудових прав мігрантів; 3) методи реалізації забезпечення трудових прав та законних інтересів мігрантів у сфері трудових правовідносин. Зроблено висновок, що форми захисту трудових прав мігрантів являють собою встановлені законодавством способи організації процедур діяльності уповноважених на це суб'єктів у межах наданих їм прав та обов'язків із поновлення порушених трудових прав, визнання таких прав, попередження їх порушення, якщо таке попередження викликано діями, що, зокрема, встановлюють дискримінаційні умови реалізації трудових прав, а також відшкодування шкоди, заподіяної порушенням трудових прав мігрантів. Форми захисту трудових прав мігрантів також доцільно класифікувати на юрисдикційні та неюрисдикційні. Специфіку реалізації цих форм зумовлено особливістю правового статусу мігранта, законністю його перебування на території країни. Самозахист трудових прав мігрантів, який уявляється доцільним віднести до неюрисдикційних форм захисту трудових прав, може бути ускладнений можливістю самостійної реалізації безпосередньо мігрантом або ж участю у самозахисті інших законних представників мігрантів.

Ключові слова: форма, правова форма, юрисдикційна форма, неюрисдикційна форма, трудові права, мігранти.
\end{abstract}

Постановка проблеми. Захист трудових прав мігрантів $\epsilon$ складовою частиною правового регулювання захисту прав людини. Т. Лісніча визначає захист прав суб'єктів правовідносин як комплекс дій правового характеру, які застосовуються в разі порушення, невизнання, оспорювання прав суб'єкта, або 3 інших визначених законом підстав, спрямованих на недопущення порушення або відновлення порушеного права, а також забезпечення дотримання інтересів суб'єкта відповідних правовідносин [1]. Мігранти є однією з найбільш уразливих категорій носіїв трудових прав, їх захист повинен охоплювати цілий комплекс заходів, передбачених нормами права. Як справедливо підкреслює Т.О. Носач, орієнтація України на вступ до ЄС передбачає необхідність реалізації цілої низки вимог, серед яких найважливішими є подолання різкого розмежування в доходах населення, досягнення високого рівня зайнятості як умови підвищення якості життя пересічних громадян, підвищення ступеню соціальної захищеності найбільш уразливих груп та всього населення, забезпечення широкого обсягу економічних та соціальних прав громадян [2, с. 138]. Захист трудових прав мігрантів як певний механізм знаходить свій прояв у відповідних формах і методах його реалізації.

Окремі проблемні питання, пов'язані із захистом трудових прав мігрантів, у своїх наукових дослідженнях розглядали: В.Д. Бакуменко, Г.В. Атаманчук, О.В. Жадан, П.О. Недбайло, Р.3. Лівшиц, Л.С. Явич, І.П. Бахровська, В.В. Молдован, А.I. Чулінда, В.М. Сирих тощо. Утім, незважаючи на чималу кількість наукових здобутків, в юридичній літературі відсутні комплексні наукові розробки, присвячені питанню форм захисту трудових прав мігрантів

Мета статті - 3'ясувати коло та надати характеристику ключовим формам захисту трудових прав мігрантів

Виклад основного матеріалу дослідження. Академічний словник української мови розкриває зміст поняття «форма» як: 1) спосіб існування змісту, його внутрішня структура, організація і зовнішній вираз; 2) тип, будова, спосіб організації чого-небудь; зовнішній вияв якого-небудь явища, пов'язаний із його сутністю, змістом [3, с. 617]. Своєю чергою, «метод» тлумачиться як: 1) спосіб пізнання явищ природи та суспільного життя; 2) прийом або система прийомів, що застосовується в якій-небудь галузі діяльності [3, с. 692]. Тобто в загальному розумінні формою можна вважати зовнішній вираз змісту захисту, тоді як метод - сукупність прийомів, що застосовуються в тій чи іншій формі діяльності, зокрема діяльності із захисту.

Відповідно до точки зору В.М. Горшеньова та І.Б. Шахова, правова форма - це специфічна організаційна форма діяльності органів держави, посадових осіб та інших уповноважених суб'єктів, яка: по-перше, здійснюється на основі найсуворішого дотримання вимог закону та інших нормативних актів; по-друге, їі результати завжди тягнуть визначені наслідки, що мають юридичне значення або пов'язані з їх настанням. Зазначені два моменти виступають в органічній єдності й є головними визначальними властивостями, а у своій сукупності кваліфікують кожну організаційну форму діяльності як правову [4, с. 37]. Науковці також дійшли висновку, що незалежно від сфери суспільних відносин для правових форм характерними $€$ такі ознаки: 1) форма діяльності завжди пов'язана 3 розгля- 
дом юридичної справи (життєвої обставини, прямо передбаченої законом чи іншим нормативним актом), що потребує відповідного підтвердження й юридичного забезпечення; 2) форма діяльності здійснюється винятково уповноваженими на те органами держави, посадовими особами та іншими суб'єктами; 3) форма діяльності завжди виражається в здійсненні операцій із нормами права; 4) результати правової форми діяльності завжди закріплюються у відповідних процесуальних документах, що мають офіційний характер і встановлену законом форму; 5) правова форма діяльності має потребу в установленні певних гарантій (відносини, що складаються в ході розгляду справ, регламентуються системою норм процесуального права); 6) правова форма діяльності безпосередньо пов'язана 3 необхідністю використання різних методів і засобів юридичної техніки [4, с. 37].

У правовій літературі висловлюються різноманітні думки щодо поняття «форма захисту трудових прав». Переважно акцентується увага саме на захисті такої категорії носіїв трудових прав, як працівник. Зокрема, I. Лагутіна форму захисту трудових прав та інтересів працівників розглядає як діяльність уповноважених органів, працівника або його представника (професійної спілки) із захисту трудових прав та законних інтересів, які виявляються у застосуванні передбачених законодавством способів і заходів, спрямованих на припинення та попередження порушень трудового законодавства, поновлення порушених трудових прав і відшкодування заподіяної шкоди $[5$, с. 7$]$. Під формами захисту трудових прав працівників, на думку М. Іншина, доцільно розуміти правовий комплекс особливих юридичних процедур, які можуть здійснювати правозастосовчі та правозахисні органи (інституції, особи) і безпосередньо працівники в межах відповідного правозахисного процесу, що мають на меті реальне відновлення порушених трудових прав та подальшу передбачену чинними нормативно-правовими актами відповідну компенсацію за їх порушення матеріального, морального чи організаційно-правового характеру. Через це під засобами захисту трудових прав працівника необхідно розуміти конкретні правові процедури, що здійснюють правозастосовчі та правозахисні органи, інституція, особи (у разі звернення до них працівника) і безпосередньо працівник у межах правозахисного процесу вибраної ним конкретної правової форми захисту порушених трудових прав [6, с. 73]. Указаними авторами під час розгляду форм захисту трудових прав звертається увага, насамперед, на процесуальний характер форм як на діяльність певних суб'єктів, що має втілюватися у конкретних юридичних процедурах.

Інші визначення концентрують увагу на матеріальному змісті форм захисту. Такі підходи мають своїм підгрунтям те, що, як зазначає В. Бурак, у матеріально-правовому аспекті право на захист включає у себе такі елементи: можливість особи, право якої порушене, використати не заборонені законом засоби примусу на порушника, у тому числі й за допомогою самозахисту; можливість особи, права якої порушені, звернутися до компетентного органу (державного чи іншого) з вимогою про захист порушеного права [7].

Зокрема, Н. Лазункова, під формою захисту розуміє комплекс внутрішньо узгоджених і врегульованих законом заходів із захисту трудових прав та законних інтересів [8, с. 209]. Форму захисту трудових прав працівників В. Андріїв розглядає як припинення порушення трудового законодавства, поновлення порушених трудових прав та відшкодування заподіяної шкоди, які здійснюються уповноваженими органами та працівниками (їхніми представниками) у визначеному порядку і відповідають установленим процесуальним вимогам [9, с. 19-20]. У цьому визначенні автором концентрується увага переважно на завданнях реалізації форм захисту трудових прав.

Як зазначає В. Журавель на основі аналізу поглядів науковців стосовно форм захисту трудових прав, існує декілька значень форми захисту трудових прав працівників: 1) як виду охоронних правовідносин у трудовому праві; 2) як інституту цивільних процесуальних правовідносин; 3) як юридична діяльність суб' єктів із поновлення, встановлення і визнання прав, свобод і законних інтересів працівників; 4) як сукупність способів та/або засобів, заходів, що мають на меті захист порушених, невизнаних, оспорюваних прав, свобод та законних інтересів працівників; 5) як система юридичних процедур, що створюють юридичні можливості поновлення, встановлення та визнання прав. На думку В. Журавель, форма захисту трудових прав працівників - це встановлений законодавством, комплекс способів, засобів і заходів організаційного і функціонального характеру, що втілені в юридичних процедурах, які здійснюються відповідними суб'єктами і спрямовані на захист порушених, невизнаних та оспорюваних прав працівників як суб'єктів трудових правовідносин [10, с. 223].

Разом із цим уявляється можливим звернути увагу на те, що доцільно розрізняти форми захисту прав працівників від форм захисту трудових прав особи, що може ще й не набути статусу працівника, зокрема у зв'язку з порушенням iï трудових прав, наприклад у процесі установлення дискримінаційних умов під час прийняття на роботу. М.М. Феськов акцентує увагу на найбільш поширених видах такої дискримінації, до них належать: застосування тестів, що мають на меті дослідження особистості працівника та його зовнішнього вигляду, привабливості, віку, світоглядних позицій, ставлення до релігії, сімейного життя, вимоги щодо вільного володіння іноземною мовою, комп'ютером під час влаштування на роботу, виконання якої такого знання не потребує [11, с. 66].

На думку Н. Гетьманцевої та I. Козуб, форма захисту - це сукупність способів, які спрямовані на поновлення, встановлення і визнання прав та законних інтересів осіб. Серед форм захисту вони виділяють: 1) звернення працівника до профспілкової організації для врегулювання розбіжностей, що виникли між ним і роботодавцем (у разі якщо такий працівник є членом профспілкової організації); 2) звернення до комісії по трудових спорах; 3) звернення до суду (у разі нестворення комісії по трудових спорах на підприємстві, в установі, організації або оскарження рішення комісії по трудових спорах); 4) звернення до інспекції або органу, що уповноважений здійснювати нагляд і контроль над дотриманням законодавства про працю; 5) звернення до прокурора за захистом трудових прав та інтересів [12].

у більшості досліджень під час визначення різновидів форм захисту трудових прав виходять із їх розподілу на юрисдикційні та неюрисдикційні, причому автори не завжди єдині в тому, які саме форми захисту трудових прав відносяться до того чи іншого різновиду.

Зокрема, за таким критерієм, як форма захисту, О. Мельничук виокремлює: а) засоби юрисдикційної форми захисту; б) засоби неюрисдикційної форми захисту, тобто самозахисту $[13$, c. 25$]$. 
I. Лагутіна у своєму дослідженні виокремлює такі різновиди форм захисту прав працівників, як юрисдикційні та неюрисдикційні. Юрисдикційні форми захисту трудових прав та інтересів працівників класифікуються нею на міжнародні та національні. Міжнародні форми включають адміністративні (контрольний механізм МОП) та судові (юрисдикція Європейського суду з прав людини). Національні юрисдикційні форми захисту включають захист трудових прав та інтересів в органах судової влади, органах із розгляду трудових спорів, а також в органах державного нагляду і контролю над додержанням законодавства про працю. Неюрисдикційні форми захисту передбачають дії працівників або їхніх представників із захисту трудових прав та інтересів, які здійснюються ними самостійно, без звернення до відповідних юрисдикційних органів (судів та адміністративних органів). Також форми захисту трудових прав та інтересів працівників класифікуються залежно від суб์'єкта, уповноваженого застосовувати передбачені законодавством способи і засоби: індивідуальний захист (самозахист); колективний захист (через профспілки, систему колективних угод і колективних договорів, органи 3 вирішення трудових спорів), державний захист (судовий захист, державний нагляд і контроль над додержанням законодавства про працю) [5, с. 8].

Як зазначає В. Бурак, у межах юрисдикційної форми розрізняють загальний i спеціальний порядок захисту трудових прав та охоронюваних законом інтересів. Загальний порядок передбачає судовий захист. Серед спеціальних форм захисту трудових прав та законних інтересів можна виділити адміністративний захист, який включає у себе захист державними органами, які здійснюють контроль дотримання трудового законодавства. Сюди також автор відносить розгляд індивідуальних трудових спорів у порядку підлеглості, який здійснюється в порядку, передбаченому законом України «Про звернення громадян», а також розгляд індивідуального трудового спору в комісії по трудових спорах. Неюрисдикційна форма захисту охоплює собою дії працівників із захисту порушених суб'єктивних прав, які здійснюються ними самостійно, без звернення до державних або інших компетентних органів. Неюрисдикційні форми захисту трудових прав та законних інтересів працівників передбачено трудовим законодавством, до них В. Бурак відносить: а) примирно-третейські процедури, які застосовуються під час вирішення колективних трудових спорів; б) самозахист; в) громадський захист, який здійснюють виборні профспілкові органи [7].

Як і інші автори, форми захисту трудових прав та інтересів працівників Н. Лазункова поділяє на два види: юрисдикційну та неюрисдикційну. Юрисдикційна форма захисту - діяльність уповноважених державою органів із захисту порушених або оспорюваних суб̄'єктивних прав. Значення юрисдикційної форми захисту полягає у тому, що особа, яка оскаржує право чи законний інтерес, звертається до державних або інших компетентних органів, на які законом покладено обов'язок прийняти необхідні заходи для відновлення порушеного права і припинення правопорушення. У межах юрисдикційної форми авторка розрізняс загальний і спеціальний порядок захисту трудових прав та охоронюваних законом інтересів. Неюрисдикційна форма захисту охоплює собою дії працівників із захисту порушених суб'єктивних прав, які здійснюються ними самостійно, без звернення до державних або інших компетентних органів. Неюрисдикційні форми захисту трудових прав та законних інтересів працівників передбачено трудовим законодавством: a) примирно-третейські процедури, які застосовуються під час вирішення колективних трудових спорів; б) самозахист; в) громадський захист, який здійснюють виборні профспілкові органи. Характерною ознакою неюрисдикційних форм захисту $\epsilon$ не вирішення спору, а сприяння сторонам спору у досягненні компромісу шляхом прийняття взаємного рішення [8, с. 209].

Розрізняючи індивідуальні та колективні форми захисту трудових прав, В. Журавель пропонує класифікацію колективних форм захисту трудових прав працівників: 1) неюрисдикційна форма захисту - колективний самозахист працівників у вигляді колективних дій; 2) юрисдикційні форми: а) захист працівників професійними спілками; б) захист працівників у порядку нагляду й контролю над дотриманням трудового законодавства уповноваженими державою органами; в) захист працівників органами, створеними для порядку розгляду колективних трудових спорів (примирна комісія, трудовий арбітраж, Національна служба 3 посередництва і примирення та ін.) $[14$, с. 76$]$.

Висновки. Таким чином, форми захисту трудових прав мігрантів являють собою встановлені законодавством способи організації процедур діяльності уповноважених на це суб̋'єктів у межах наданих їм прав та обов'язків із поновлення порушених трудових прав, визнання таких прав, попередження їх порушення, якщо таке попередження викликано діями, що, зокрема, встановлюють дискримінаційні умови реалізації трудових прав, а також відшкодування шкоди, заподіяної порушенням трудових прав мігрантів. Форми захисту трудових прав мігрантів також доцільно класифікувати на юрисдикційні та неюрисдикційні. Специфіку реалізації цих форм зумовлено особливістю правового статусу мігранта, законністю його перебування на території країни. Самозахист трудових прав мігрантів, який уявляється доцільним віднести до неюрисдикційних форм захисту трудових прав, може бути ускладнений можливістю самостійної реалізації безпосередньо мігрантом або ж участю у самозахисті інших законних представників мігрантів.

Значення форм захисту трудових прав мігрантів полягає у тому, що їх правове регулювання визначас: 1) можливе коло суб'єктів, що приймають участь у відносинах із захисту трудових прав мігрантів за такої форми; 2) певну модель поведінки учасників правовідносин із захисту трудових прав мігрантів; 3) методи реалізації забезпечення трудових прав та законних інтересів мігрантів у сфері трудових правовідносин.

\section{Jimepamypa:}

1. Лісніча Т.В. Особливості господарсько-правового захисту прав суб'єктів господарювання. URL: https://periodicals.karazin.ua/jls/ article/view/1685.

2. Носач Т.О. Реалізація права на працю людей з особливими потребами. Проблеми захисту прав та свобод людини і громадянина : тези Міжнародної науково-практичної конференції молодих вчених та студентів, м. Чернігів, 22-23 травня 2014 р. Чернігів : Десна Поліграф, 2014. 696 с.

3. Словник української мови : в 11 т. / АН Української РСР, Ін-т мовознав. ім. О.О. Потебні ; редкол.: І.К. Білодід (гол.) та ін. Київ : Наук. думка, 1970-1980. Т. 10. 658 с.

4. Горшенев В.М., Шахов И.Б. Контроль как правовая форма деятельности. Москва : Юрид. лит., 1987. 176 с.

5. Лагутіна I.В. Форми захисту трудових прав працівників : автореф дис. ... канд. юрид. наук : 12.00 .05 - трудове право; право соціального забезпечення. Одеса. 2007. 22 с. 
6. Іншин І.М. Захист трудових прав працівників в сучасних умовах. Сучасні виклики украӥнського права у контексті європейської iнтеграиіï. 2016. № 1(1). С. 71-74.

7. Бурак В. До поняття правового захисту трудових прав працівників. URL: http://www.pravoznavec.com.ua/period/article/18034/\%C2.

8. Лазукова Н.В. Гарантії та форми захисту прав людини у сфері праці. Молодий вчений. 2015. № 1(16). С. 208-211.

9. Андріїв В.М. Система трудових прав працівників та механізм їх забезпечення : автореф. дис. ... д-ра. юрид. наук : 12.00.05. Одеса, 2012. $40 \mathrm{c}$.

10. Журавель В.І. Поняття форм захисту трудових прав працівників. Форум права. 2013. № 3. С. 219-225.

11. Феськов М.М. Трудове законодавство України і Європейська соціальна хартія (переглянута): питання адаптації. Київ : Знання, 2005. $276 \mathrm{c}$.

12. Способи захисту прав та свобод людини і громадянина. Городоцька районна державна адміністрація : офіційний сайт. URL: http://www.gorodok-vlada.gov.ua/node/29030.

13. Мельничук О.Ф. Правові засоби та способи захисту суб'єктивного права на освіту. Адвокат. 2011. № 4(127). С. 23-27.

14. Журавель В. Принципи та види колективних форм захисту трудових прав працівників. Підприємництво, господарство і право. 2016. № 2. C. 74-77.

Kozin S. To characterize the forms of protection of labor rights of migrants

Summary. The article, based on the analysis of scientific views of scientists and the current legislation of Ukraine, clarifies the range and provides a description of the key forms of protection of labor rights of migrants. It is noted that the forms of protection of labor rights of migrants should be classified into jurisdictional and non-jurisdictional. It is substantiated that the specifics of the implementation of the forms defined in the article are due to the peculiarity of the legal status of the migrant, the legality of his stay in the country. It is emphasized that among the special forms of protection of labor rights and legitimate interests can be distinguished administrative protection, which includes protection by state bodies that monitor compliance with labor legislation. It was found that the importance of forms of protection of labor rights of migrants is that their legal regulation determines: 1) the possible range of entities involved in the protection of labor rights of migrants in this form; 2) determine a certain model of behavior of participants in legal relations to protect the labor rights of migrants; 3 ) determine the methods of implementation of labor rights and legitimate interests of migrants in the field of labor relations. It is concluded that the forms of protection of labor rights of migrants are statutory methods of organizing the activities of authorized entities within the rights and responsibilities granted to them to restore violated labor rights, recognition of such rights, prevention of their violation, if such warning is caused actions that, in particular, establish discriminatory conditions for the exercise of labor rights, as well as compensation for damage caused by the violation of labor rights of migrants. Forms of protection of labor rights of migrants should also be classified into jurisdictional and non-jurisdictional. The specificity of the implementation of these forms is due to the peculiarity of the legal status of the migrant, the legality of his stay in the country. Selfdefense of migrants' labor rights, which seems appropriate to be classified as non-jurisdictional forms of labor rights protection, may be complicated by factors such as the possibility of self-realization directly by the migrant, or participation in self-defense of other legal representatives of migrants.

Key words: form, legal form, jurisdictional form, non jurisdictional form, labor rights, migrants. 